\title{
Improved Model for Semideciduous Seasonal Forest Production of Leaves and Deciduousness
}

\author{
Thomaz Costa \\ Core of Water, Soil and Environmental Sustainability (NSAM), Embrapa Maize and Sorghum, Sete Lagoas 35701-970, Brazil
}

\begin{abstract}
The climate, mainly the water availability and temperature, drives the renewal of biomass in seasonal forest ecosystem, and the greenness and leaf area of its canopy are responsive by climate variations. This study verified models to explain the phenomenon of leaf production and deciduousness by time, with LAI (Leaf Area Index), NDVI (Normalized Difference Vegetation Index) and climate variables, on period 2011-2016. The data were obtained in satellite images and in plots installed at forest monitoring sites, visited monthly. The analysis incorporated the water balance. Three equations were compared, two already published and the equation that was adjusted in this work. The model was improved and validated with new variables and data. It is possible to estimate the fall and renew of leaves biomass in semideciduous forests with reasonable precision.
\end{abstract}

Key words: Ecosystem dynamics, climate variables, LAI, NDVI.

\section{Introduction}

Leaf production and deciduousness are phenomena that occur with a little temporal overlay in semideciduous forests, because it is a typology conditioned by tropical climatic seasonality, with a period of intense summer rains, and another of severe drought, dependent of the dynamics of soil water and change of temperature [1].

The sprouting and leaf growth, the senescence and the leaf fall are crucial for forestry ecosystem maintenance and for survival through the nutrient cycling sustained by deciduousness. The fall of leaves, branches, flowers and fruits supply organic material to the surface layer of the soil, nourishing the plant species. Using this process, nutrients are deposited and mineralized, maintaining the soil fertility in these ecosystems [2-4].

The type of vegetation (floristic diversity) and the environmental conditions (temperature and water stress) influence the distribution, quantity and quality of these materials, which form the litterfall [5-7].

Corresponding author: Thomaz Costa, Ph.D., main research field: remote sensing of vegetation.
The quantity of material that falls from the canopy, forming the litterfall, reaches a rate of tons per hectare/year. The forest starts producing leaves again in rainy season beginning, renewing the lost biomass. Potithep, S., et al. [8] and Kale, M., et al. [9] stablished two stages in deciduous tropical forests, leaf growth and senescence.

In order to understand the year-to-year cycling pattern of the carbon in the terrestrial ecosystems, attempts to detect the vegetation phenological patterns by remote sensing had been made, especially after the release of the MODIS (Moderate Resolution Imaging Spectroradiometer) sensor, with calibration quality and the products provided, such as LAI (Leaf Area Index) and fAPAR (fraction of Absorbed Photosynthetically Active Radiation) [10-12].

One part of this carbon is in deciduousness phenomenon that can be modeled by means of relationships with climatic, biophysics and orbital variables, allowing estimates of leaf fall [13] and annual $\mathrm{CO}_{2}$ capture estimates [14]. However, this modelling still needs improvement, which is the objective of this work.

\section{Material and Methods}




\subsection{Study Site}

The Köppen climatic classification for Sete Lagoas is Cwa [15], which indicates Savana climate with dry winter and rainy summer. The annual average temperature is $21.1{ }^{\circ} \mathrm{C}$. The annual rainfall is 1,384 $\mathrm{mm}$ and the annual evapotranspiration is around 1,444 $\mathrm{mm}[16]$.

The monitoring was done in three sites $(51,61$ and 81) of the semideciduous seasonal forest at biome Savanna, at the Experimental Farm of Embrapa Mize and Sorghum, which is located in the city of Sete Lagoas, State of Minas Gerais, Brazil (Fig. 1), characterized by the parameters of Table 1 .

Sites 51 and 61 are in remnants of the semideciduous seasonal forest. The site 51 is on
Ultisols Dystrophic Typic and the sites 61 and 81 are on Inceptisols Humic Dystrophic Typic class [17]. The difference among them is that site 81 is close to water bodies.

\subsection{Variables and Procedures}

The Thornthwaite water balance was calculated from 2011 until October 2016 with daily data of PET (Potential Evapo Transpiration). This procedure is explained in Costa, T. C. C., et al. [14]. The maximum and minimum temperature, relative humidity and wind speed were average on deciduousness periods. The daily values of evapotranspiration, rain, hydric deficit and hydric surplus were accumulated on deciduousness periods.

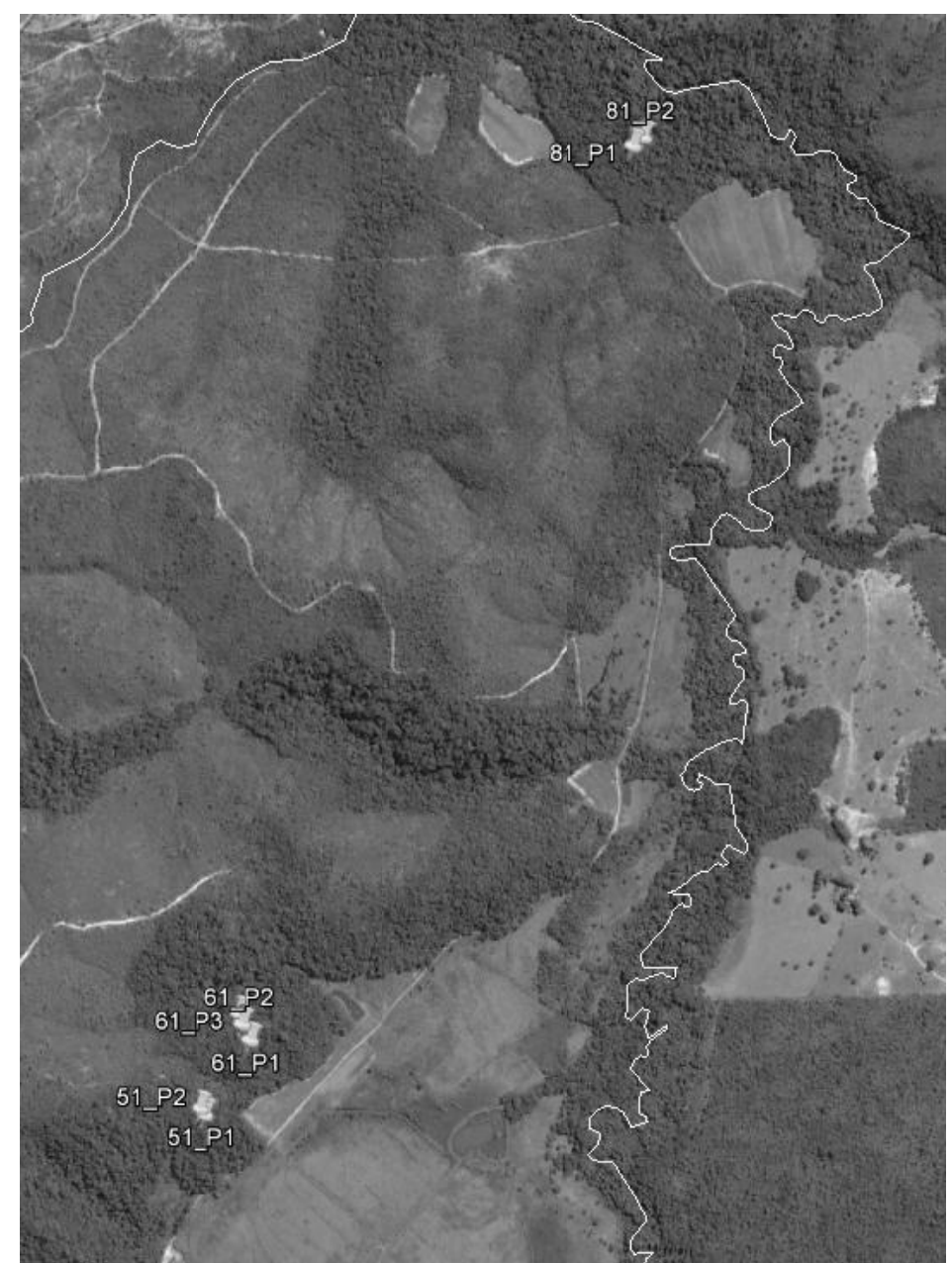

Fig. 1 Location of the sites 51, 61 and 81 in fragment of the north side of the Embrapa Farm, Sete Lagoas, Minas Gerais, Brazil.

Table 1 Coordinates (X, Y) UTM/23 Zone WGS84 of plots with $20 \times 20$ meters; five nets in each plot; geometric altitude (Z); 
declination in degrees (Decl); individual density (ind $\left.\cdot \mathrm{m}^{-2}\right)$; basal area (B); average tree height (H); Shannon index (H'); Simpson dominance index $(C)$ and period of collects.

\begin{tabular}{llllllllllll}
\hline Site & Plot & $\mathrm{X}(\mathrm{m})$ & $\mathrm{Y}(\mathrm{m})$ & $\mathrm{Z}(\mathrm{m})$ & $\mathrm{Decl}\left({ }^{\circ}\right)$ & $\mathrm{D}\left(\mathrm{arv} . / \mathrm{m}^{2}\right)$ & $\mathrm{B}\left(\mathrm{m}^{2} / \mathrm{ha}\right)$ & $\begin{array}{l}\text { Tree } \\
\text { height }(\mathrm{m})\end{array}$ & $\mathrm{H}{ }^{\prime}$ & $\mathrm{C}$ & Collec. Dlw \\
\hline 51 & 1 & 588,363 & $7,851,128$ & 713 & 10.2 & 0.08 & 15 & 10.4 & 2.73 & 0.05 & $2011 / 12$ \\
& 2 & 588,352 & $7,851,142$ & 724 & 7.2 & 0.10 & 36 & 11.8 & 2.55 & 0.08 & $2011 / 12$ \\
61 & 1 & 588,458 & $7,851,281$ & 736 & 14.1 & 0.08 & 16 & 8.7 & 2.19 & 0.11 & $2011 / 12$ \\
& 2 & 588,441 & $7,851,313$ & 735 & 11.2 & 0.10 & 26 & 12.0 & 2.20 & 0.15 & $2011 / 12$ \\
& 3 & 588,434 & $7,851,334$ & 729 & 7.0 & 0.08 & 18 & 11.7 & 3.03 & 0.02 & $2011 / 12,2015 / 16$ \\
81 & 1 & 589,268 & $7,853,121$ & 707 & 6.2 & 0.19 & 33 & 9.0 & 2.88 & 0.07 & $2011 / 12,2014 / 15$ \\
& 2 & 589,289 & $7,853,140$ & 707 & 7.0 & 0.17 & 30 & 9.4 & 2.85 & 0.07 & $2011 / 12$ \\
\hline
\end{tabular}

In order to measure the deciduousness data, it was used permanent plots of the inventory, to gather of the deposition of litterfall in the nets. The collections were carried out monthly in the approximate period of 30 days. The dry leaves variable $\left(\mathrm{g} \cdot \mathrm{m}^{-2}\right)$ is the average of the five nets in each plot. The leaf area $\left(\mathrm{m}^{2}\right.$ of leaf $x$ $\mathrm{m}^{-2}$ of soil) was measured with the LAI 2200 Plant Canopy Analyzer [18]. The procedures were described by Costa, T. C. C., et al. [14].

It was selected three Landsat TM 5 images, as they coincide with their final reception, complementing the period with seven images of the IRS LISS3 (Indian Remote Sensing Satellite), a sensor with characteristics closer to Landsat. The main differences between them are the spatial (30 $\mathrm{m}$ and $24 \mathrm{~m}$ pixel) and radiometric ( 8 and 7 bits) resolutions, and a small difference in the range of the spectral bands. In 2013, it was used Landsat 8 OLI images with radiometric resolution of 16 bits, and shorter amplitude band compared with Landsat TM 5, mainly in near infrared band.

The geometrical correction was performed in Geotiff Examiner software, with the aid of the graphic software Inkscape, using a reference point to dislocate the images. This form of correction was more precise compared to the polynomial corrections, even with RMS smaller than $1 / 2$ pixel. In order to extract NDVI (Normalized Difference Vegetation Index) in each permanent plot, it was digitalized a rectangle of nine pixels centralized in the central point of the permanent plot. For Landsat 8 OLI images, geometric corrections were not necessary.
The atmospheric correction was performed with an ATMOSC (Atmospherically Correcting model) module of Idrisi Taiga@, using the full model [19]. The Dn Raze (portion of the spectral response caused by the interference of the atmosphere by scattering and absorption of the radiation in digital number format) [19] was obtained through the smaller spectral response of the visible and near infrared bands, in points of the lakes on region, compared with Gürtler, P. S. J.'s [20] procedure. It was based on the atmosphere correction method of Chavez, S., et al. [21]. All images have visibility above $10 \mathrm{~km}$ (information from air traffic control service bulletin of Confins Airport, State of Minas Gerais, Brazil).

The atmosphere optical dimension is the sum of the main components Rayleigh scattering, aerosols scattering and absorption, water vapor and typical ozone absorption. The Rayleigh scattering was adjusted to local height with atmospheric pressure data. The water vapor component was obtained for the NIR (Near Infrared), in function of the relative humidity [19] using the linear relation [14].

The quantity of diffuse energy in relation to the total energy was estimated by SPECTRAL2 model, described in Bird, R. E. and Riordan, C. [22], with the following input parameters: AOD (Aerosol Optical Depth $)=\exp ($-altitude $(\mathrm{km}) / 1.2) \times 0.2$; albedo; turbity coefficient; column ozone, in centimeters; PWV (Precipitable Water Vapor), in $\mathrm{cm}$, calculated with Abdullrahman Maghrabi and Dajani formulas [23]; pressure of air (mha); and usual variables (satellite 
time in hour, decimal minute), degree and azimuth of surface.

\subsection{Monitoring Period}

It was analyzed three variables: dry leaf weight $\left(\mathrm{g} \cdot \mathrm{m}^{-2} \cdot\right.$ period $\left.^{-1}\right)$, LAI $\left(\mathrm{m}^{2} \cdot \mathrm{m}^{-2}\right)$ and NDVI, from 2011 to 2016 (Table 2). The measures were made on approximate days of the month.

In order to obtain data on the same days of the dry leaves collected, NDVI and LAI data were interpolated using the dates. It did not measure the absence of some data in the periods because of project closure (end of support in data collection). Besides, an unforeseen malfunction of the Lai 2200 happened, which resulted in the lack of data between April and July 2016. Regarding the few NDVI data, the justification is the use of only high quality images.

\subsection{Improvement of Dry Leaf Weight Modeling}

It was compared results of three equations, published in Costa, T. C. C., et al. $[13,14]$, and those developed in this work.

Table 2 Data of dry leaves weight, LAI and NDVI, of the Landsat 5 TM (08/20/11-09/21/11), IRS (02/08/12-10/05/12), e Landsat 8 OLI (08/09/13-09/13/16) images, with respective days of the year.

\begin{tabular}{|c|c|c|c|c|c|c|c|c|c|c|c|c|c|}
\hline Per. & $\begin{array}{l}\text { Leaves } \\
\left(\mathrm{g} / \mathrm{m}^{2}\right)\end{array}$ & & $\begin{array}{l}\text { LAI } \\
\left(\mathrm{m}^{2} / \mathrm{m}^{2}\right)\end{array}$ & & NDVI & & Per. & $\begin{array}{l}\text { Leaves } \\
\left(\mathrm{g} / \mathrm{m}^{2}\right)\end{array}$ & & $\begin{array}{l}\text { LAI } \\
\left(\mathrm{m}^{2} / \mathrm{m}^{2}\right)\end{array}$ & & NDVI & \\
\hline & Date & Day & Date & Day & Date & Day & & Date & Day & Date & Day & Date & Day \\
\hline \multirow[t]{16}{*}{1} & $07 / 15 / 11$ & 196 & & & & & 3 & $08 / 27 / 14$ & 239 & $08 / 14 / 14$ & 226 & $08 / 12 / 14$ & 224 \\
\hline & $08 / 15 / 11$ & 227 & & & $08 / 20 / 11$ & 232 & & $09 / 26 / 14$ & 269 & $09 / 16 / 14$ & 259 & $08 / 28 / 14$ & 240 \\
\hline & $09 / 13 / 11$ & 256 & $09 / 13 / 11$ & 256 & $09 / 05 / 11$ & 248 & & $10 / 28 / 14$ & 301 & $10 / 20 / 14$ & 293 & $09 / 13 / 14$ & 256 \\
\hline & $10 / 18 / 11$ & 291 & $10 / 19 / 11$ & 292 & $09 / 21 / 11$ & 264 & & $11 / 26 / 14$ & 330 & $11 / 19 / 14$ & 323 & $10 / 15 / 14$ & 288 \\
\hline & $11 / 16 / 11$ & 320 & $11 / 16 / 11$ & 320 & & & & $12 / 23 / 14$ & 357 & $12 / 15 / 14$ & 349 & $12 / 18 / 14$ & 352 \\
\hline & $12 / 14 / 11$ & 348 & $12 / 12 / 11$ & 346 & & & & $01 / 29 / 15$ & 394 & $01 / 23 / 15$ & 388 & & \\
\hline & $01 / 16 / 12$ & 381 & $01 / 15 / 12$ & 380 & & & & $02 / 27 / 15$ & 423 & $02 / 27 / 15$ & 423 & & \\
\hline & $02 / 14 / 12$ & 410 & $02 / 10 / 12$ & 406 & $02 / 08 / 12$ & 404 & & $03 / 27 / 15$ & 451 & $03 / 27 / 15$ & 451 & & \\
\hline & $03 / 15 / 12$ & 440 & $03 / 13 / 12$ & 438 & $03 / 03 / 12$ & 428 & & $04 / 29 / 15$ & 484 & $04 / 30 / 15$ & 485 & & \\
\hline & $04 / 15 / 12$ & 471 & $04 / 17 / 12$ & 473 & $04 / 20 / 12$ & 476 & & $05 / 27 / 15$ & 512 & $05 / 29 / 15$ & 514 & $05 / 27 / 15$ & 512 \\
\hline & $05 / 14 / 12$ & 500 & $05 / 08 / 12$ & 494 & & & & $06 / 28 / 15$ & 544 & $06 / 26 / 15$ & 542 & & \\
\hline & $06 / 15 / 12$ & 532 & $06 / 20 / 12$ & 537 & $07 / 01 / 12$ & 548 & & $07 / 28 / 15$ & 574 & $07 / 17 / 15$ & 563 & $07 / 30 / 15$ & 576 \\
\hline & $07 / 15 / 12$ & 562 & $07 / 13 / 12$ & 560 & $07 / 25 / 12$ & 572 & 4 & $08 / 28 / 15$ & 240 & $08 / 21 / 15$ & 233 & $08 / 15 / 15$ & 226 \\
\hline & $08 / 14 / 12$ & 592 & $08 / 14 / 12$ & 592 & & & & $09 / 30 / 15$ & 273 & $09 / 25 / 15$ & 268 & $09 / 16 / 15$ & 258 \\
\hline & $09 / 13 / 12$ & 622 & $09 / 13 / 12$ & 622 & $09 / 11 / 12$ & 620 & & $10 / 30 / 15$ & 303 & $10 / 29 / 15$ & 302 & $10 / 02 / 15$ & 274 \\
\hline & & & $10 / 17 / 12$ & 656 & $10 / 05 / 12$ & 644 & & $11 / 30 / 15$ & 334 & $11 / 25 / 15$ & 329 & & \\
\hline \multirow[t]{12}{*}{2} & & & $08 / 15 / 13$ & 227 & $08 / 09 / 13$ & 221 & & $12 / 29 / 15$ & 363 & $12 / 18 / 15$ & 352 & & \\
\hline & & & $09 / 16 / 13$ & 259 & $09 / 26 / 13$ & 269 & & $01 / 29 / 16$ & 394 & $01 / 25 / 16$ & 390 & & \\
\hline & & & $10 / 15 / 13$ & 288 & $10 / 28 / 13$ & 301 & & $02 / 26 / 16$ & 422 & $02 / 27 / 16$ & 423 & & \\
\hline & & & $11 / 18 / 13$ & 322 & $11 / 13 / 13$ & 317 & & $03 / 28 / 16$ & 453 & $04 / 01 / 16$ & 457 & & \\
\hline & & & $12 / 17 / 13$ & 351 & & & & $04 / 28 / 16$ & 484 & & & & \\
\hline & & & $01 / 27 / 14$ & 392 & $01 / 16 / 14$ & 381 & & $05 / 30 / 16$ & 516 & & & & \\
\hline & & & $02 / 17 / 14$ & 413 & & & & $06 / 30 / 16$ & 547 & & & & \\
\hline & & & $03 / 17 / 14$ & 441 & & & & $07 / 29 / 16$ & 576 & & & & \\
\hline & & & $04 / 22 / 14$ & 477 & $04 / 22 / 14$ & 477 & & & & $08 / 19 / 16$ & 597 & $08 / 17 / 16$ & 594 \\
\hline & & & $05 / 20 / 14$ & 505 & $06 / 09 / 14$ & 525 & & & & & & & \\
\hline & & & $06 / 18 / 14$ & 534 & $06 / 25 / 14$ & 541 & & & & & & & \\
\hline & & & $07 / 21 / 14$ & 567 & $07 / 11 / 14$ & 557 & & & & & & & \\
\hline
\end{tabular}




\section{Results and Discussion}

The region where this experiment was carried out has tropical climatic seasonality. Its rainy season ranges from October to March, and the dry season, from April to September. Fig. 2 presents the water balance for the period of study. The difference between surplus and deficit of the water was not made because in this case the short sequence of days without rain is not visible in data analysis. This condition is important in analysis because hydric deficit has relation with deciduousness in summer period.

In Table 3, it can see the correlations of LAI with climate variables. LAI correlates with NDVI (Fig. 3), relative humidity, rain, evapotranspiration, deficiency

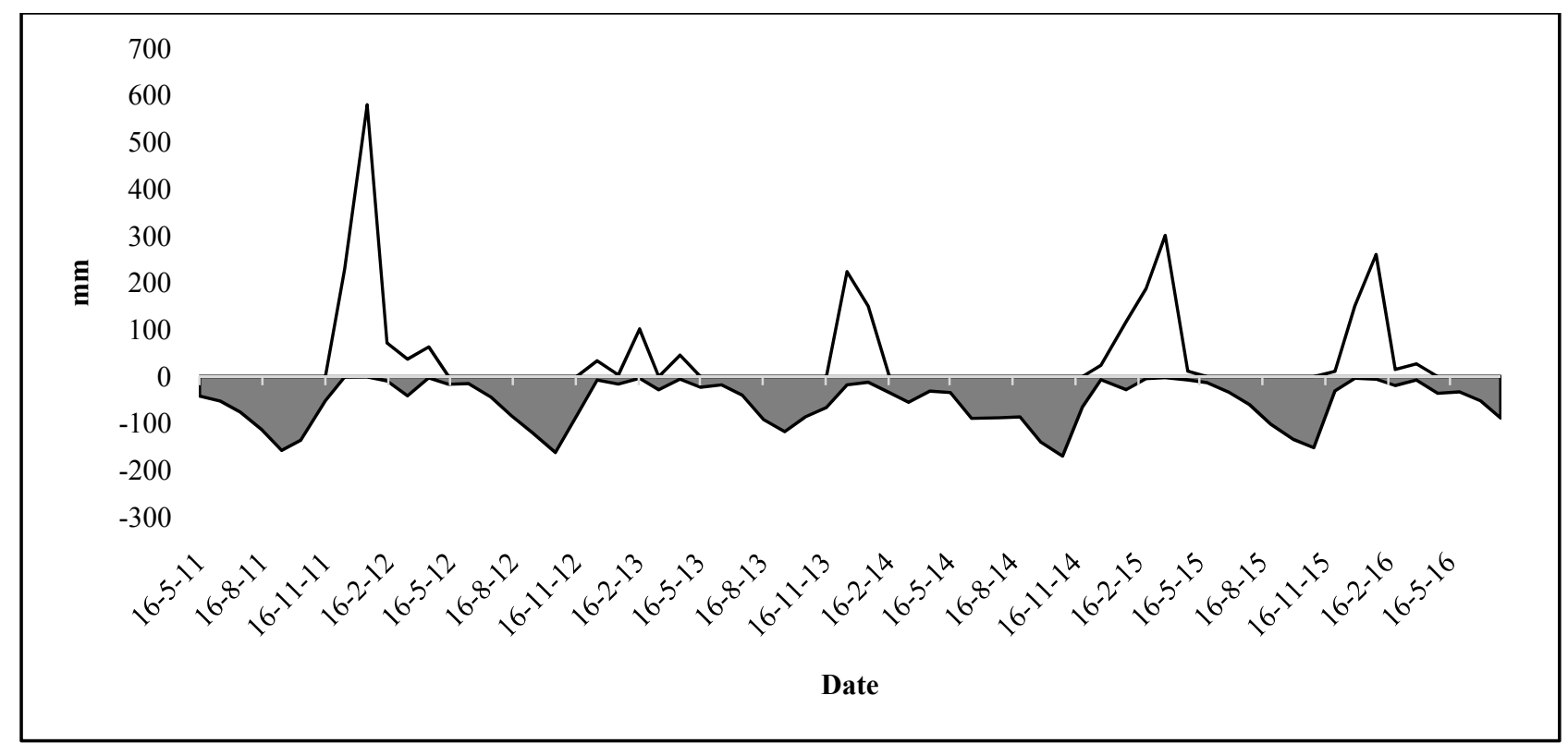

Fig. 2 Accumulated daily climatic water balance of Thornthwaite. Note: DEF (Deficiency) and EXC (Surplus) water to CAD $=150 \mathrm{~mm}$, establishing the same accumulation period of the fallen leaves.

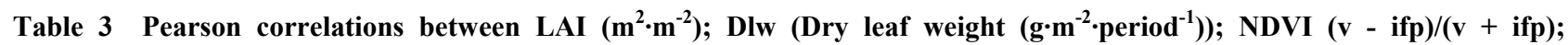
Maximum Temperature ${ }^{\circ} \mathrm{C}$ (TMax); Minimum Temperature ${ }^{\circ} \mathrm{C}$ (TMin); Relative Humidity \% on 12h (RH12) and on 18h (RH18); Ppt (Rain); ETR (Reference Evapotranspiration); DEF (Water Deficiency (mm)); EXC (Water Excess (mm)); speed wind on 12h (SpWin12) and on 18h (SpWin18). (ns: non-significant at 0.05 of probability, $n=84)$.

\begin{tabular}{|c|c|c|c|c|c|c|c|c|c|c|c|c|}
\hline Variables & LAI & Dlw & NDVI & TMax & TMin & RH12 & RH18 & $\mathrm{Ppt}$ & ETR & $\operatorname{DEF}(-)$ & EXC & SpWin12 \\
\hline Dlw & -0.53 & & & & & & & & & & & \\
\hline NDVI & 0.52 & -0.28 & & & & & & & & & & \\
\hline TMax & ns 0.01 & ns 0.00 & 0.47 & & & & & & & & & \\
\hline TMin & 0.54 & -0.70 & 0.54 & 0.34 & & & & & & & & \\
\hline UR12 & 0.53 & -0.58 & ns 0.05 & -0.62 & 0.35 & & & & & & & \\
\hline UR18 & 0.55 & -0.70 & ns 0.17 & -0.43 & 0.65 & 0.90 & & & & & & \\
\hline Ppt & 0.41 & -0.47 & ns 0.17 & ns -0.19 & 0.66 & 0.65 & 0.78 & & & & & \\
\hline ETR & -0.54 & 0.57 & ns -0.01 & 0.64 & -0.23 & -0.93 & -0.82 & -0.50 & & & & \\
\hline DEF(-) & 0.70 & -0.71 & ns 0.20 & -0.42 & 0.43 & 0.89 & 0.82 & 0.49 & -0.93 & & & \\
\hline EXC & 0.34 & -0.35 & ns 0.11 & -0.24 & 0.52 & 0.63 & 0.70 & 0.97 & -0.49 & 0.43 & & \\
\hline SpWin12 & -0.47 & 0.49 & ns -0.05 & 0.58 & ns -0.10 & -0.86 & -0.67 & -0.42 & 0.88 & -0.83 & -0.42 & \\
\hline SpWin18 & -0.37 & 0.55 & ns -0.16 & 0.38 & -0.28 & -0.62 & -0.66 & -0.23 & 0.69 & -0.64 & ns -0.17 & 0.71 \\
\hline
\end{tabular}

(-): negative values. 


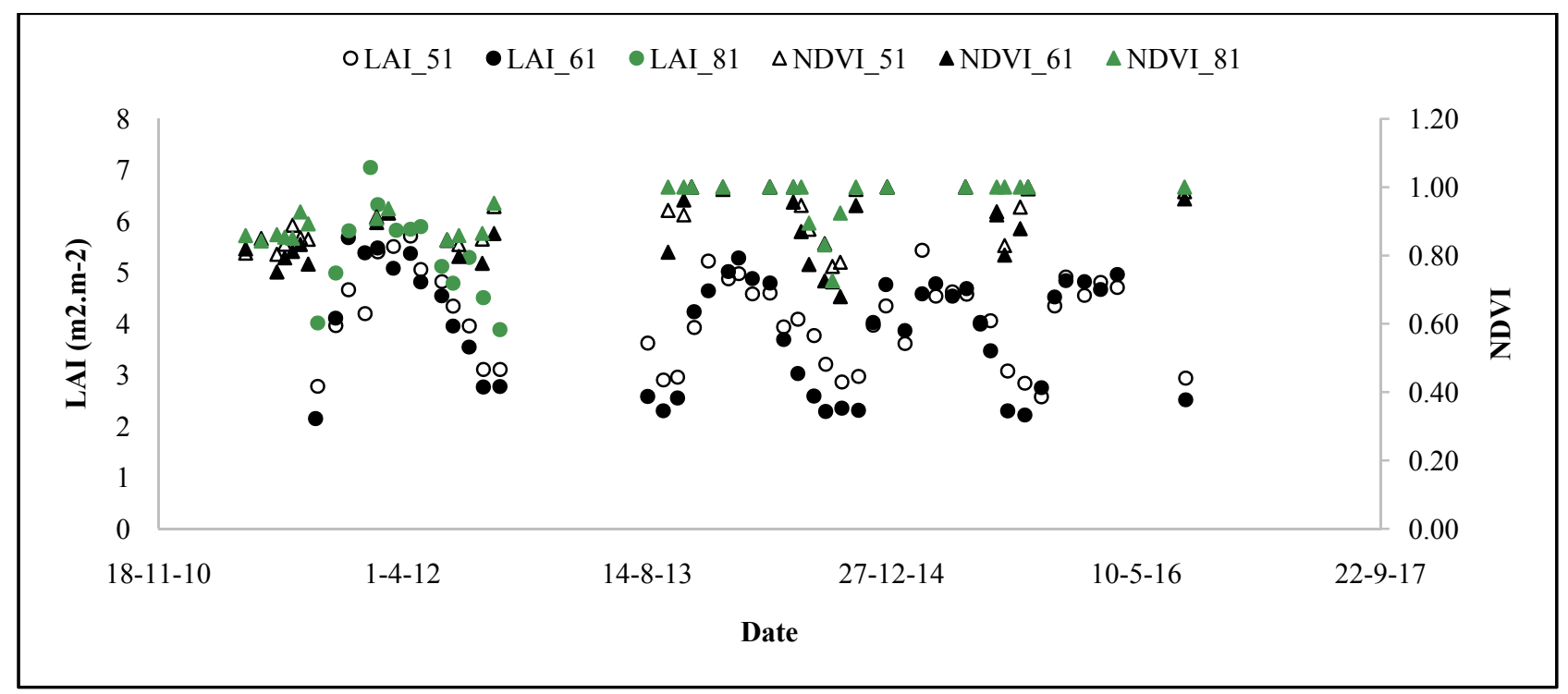

Fig. 3 Relations between NDVI and LAI in sites 51, 61 and 81.

and surplus hydric. LAI also correlates with wind speed and dry leaves, but with opposite signal, in consistent way as well.

LAI had bigger correlation with dry leaf than NDVI (Figs. 4 and 5). The values of NDVI do not have great precision yet due to lower image resolutions and because image processing does not remove all atmospheric interference of the signal.

LAI has a strong relationship with the deciduousness in this forest typology. The increase of LAI indicates that the sprouting and growth of leaves increase until a maximum, synchronously with the reduction of deciduousness, when it reaches a minimum, and the reduction of leaf area starts, synchronously with the increase of the deciduousness. In this stage, the deciduousness drives the reduction of LAI, because in this period the leaf production practically stops.

Figs. 6-9 show graphical relationships between dry leaf and climate variables to sites 51, 61 and 81 . Deciduousness phenomenon explains the expected relationships. The dry leaves have significant correlation with all variables, exception to maximum temperature (Fig. 6). The large correlations of dry leaves occurred with minimal temperature and hydric deficiency variables (Figs. 6 and 8) is the main cause of deciduousness.

On site 81 , NDVI of images of Landsat 8 OLI was saturated a few times (Fig. 5), perhaps due to large values of green biomass. NDVI saturation in dense plant coverage affects the relation between LAI and NDVI, which occurs especially in ombrophilous typologies. The site 81 is classified as rain forest by IBGE, and is predominantly classified as Seasonal forest always green by Costa, T. C. C., et al. [24]. Another possible cause of NDVI saturation is amplitude changes of red and near infrared bands in Landsat 8 . Roy, D. P., et al. [25] verified that, in Landsat 8, NDVI is in average 5\% bigger than in Landsat 7.

\subsection{Regression Model}

The deciduousness relationship with each descriptor variable (LAI, NDVI, temperature, relative humidity, evapotranspiration, rain, water balance and wind speed) generated the better equation with polynomial model on Eq. (1), with $\mathrm{R}^{2}=80.7 \%$.

$$
\begin{array}{r}
D l w\left(g . m^{-2} . \text { month }^{-1}\right)=26.0807+19.5211 \times \\
L A I-50.0720 \times N D V I-4.2752 \times \text { TMin }+ \\
0.3567 \times U R 18-0.1356 \times D E F-21.47 \times
\end{array}
$$

WinSp18 - $1.7907 \times L A I^{2}+77.6983 \times N D V I^{2}-$ $0.0965 \times$ TMin $^{2}+0.00388 \times U R 18^{2}+0.000795 \times$

$$
D E F^{2}+10.3549 \times W i n S p 18^{2}
$$




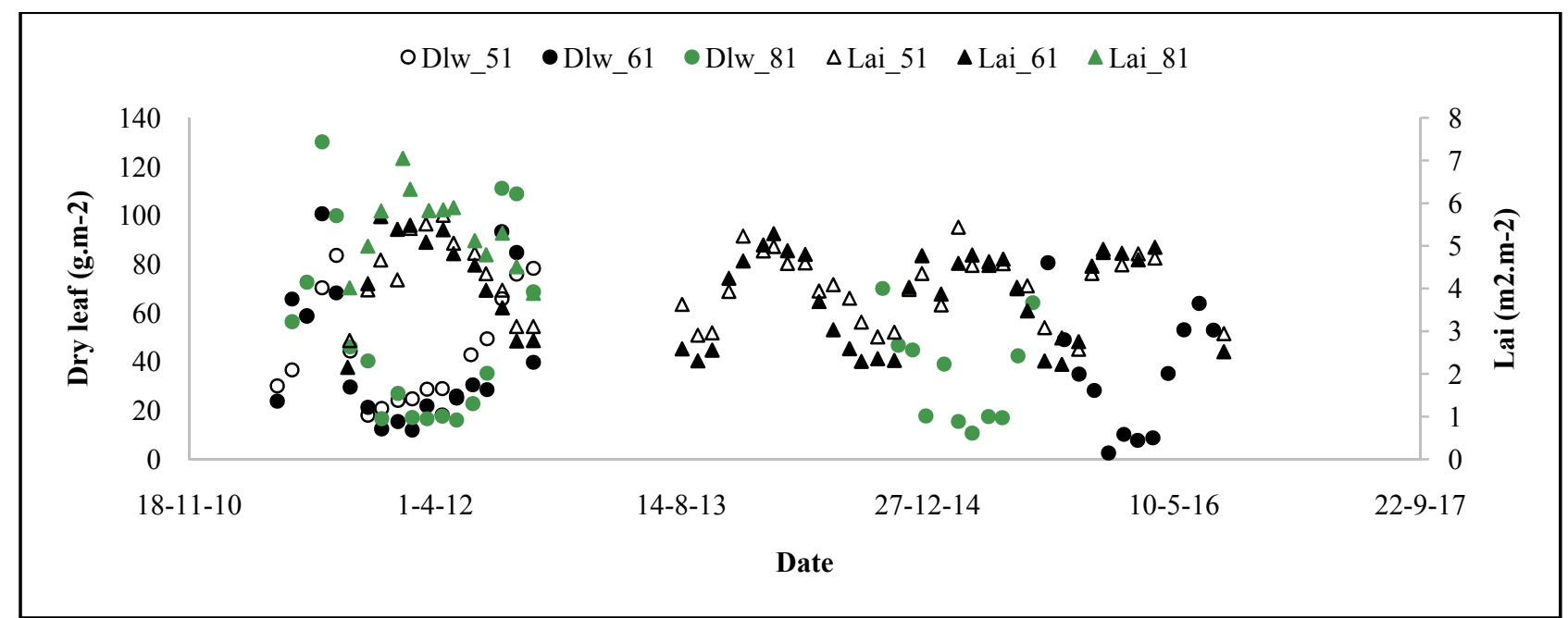

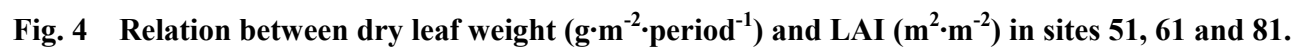

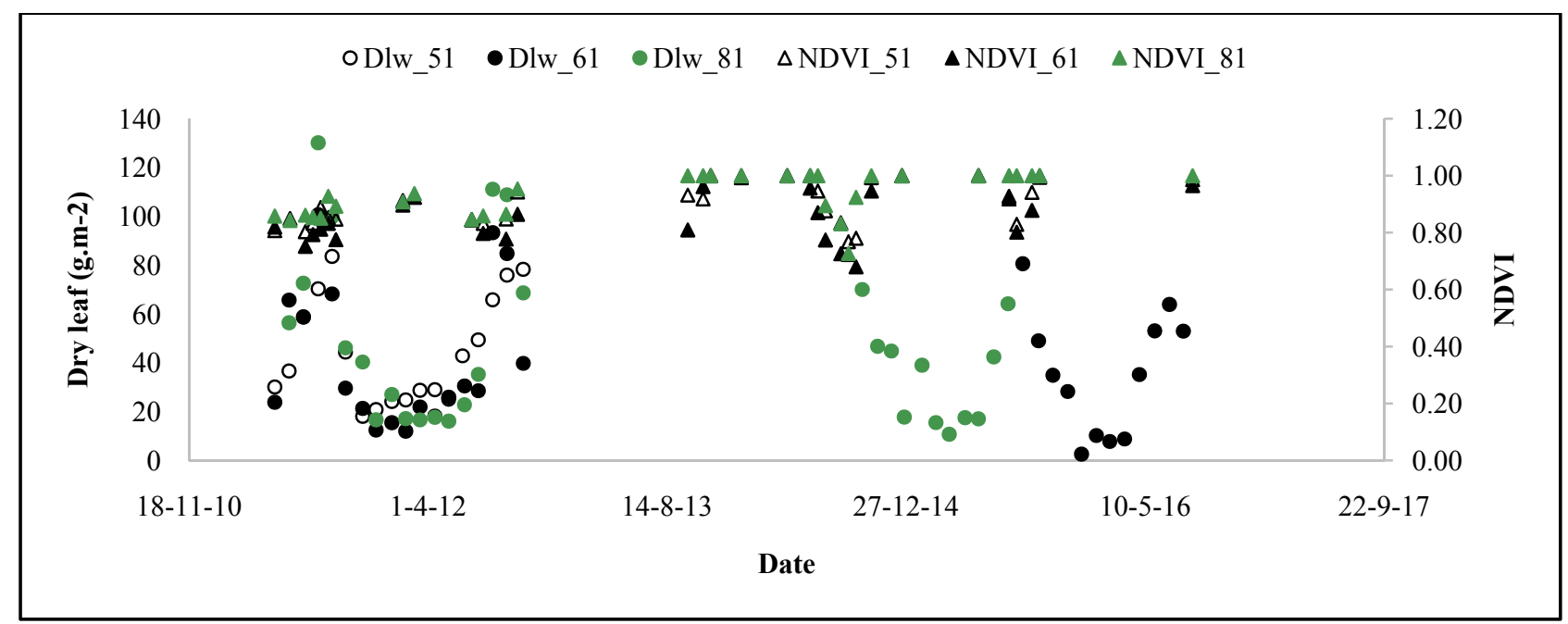

Fig. 5 Relations between dry leaf weight $\left(\mathrm{g} \cdot \mathrm{m}^{-2} \cdot\right.$ period $\left.^{-1}\right)$ and NDVI in sites 51,61 and 81.

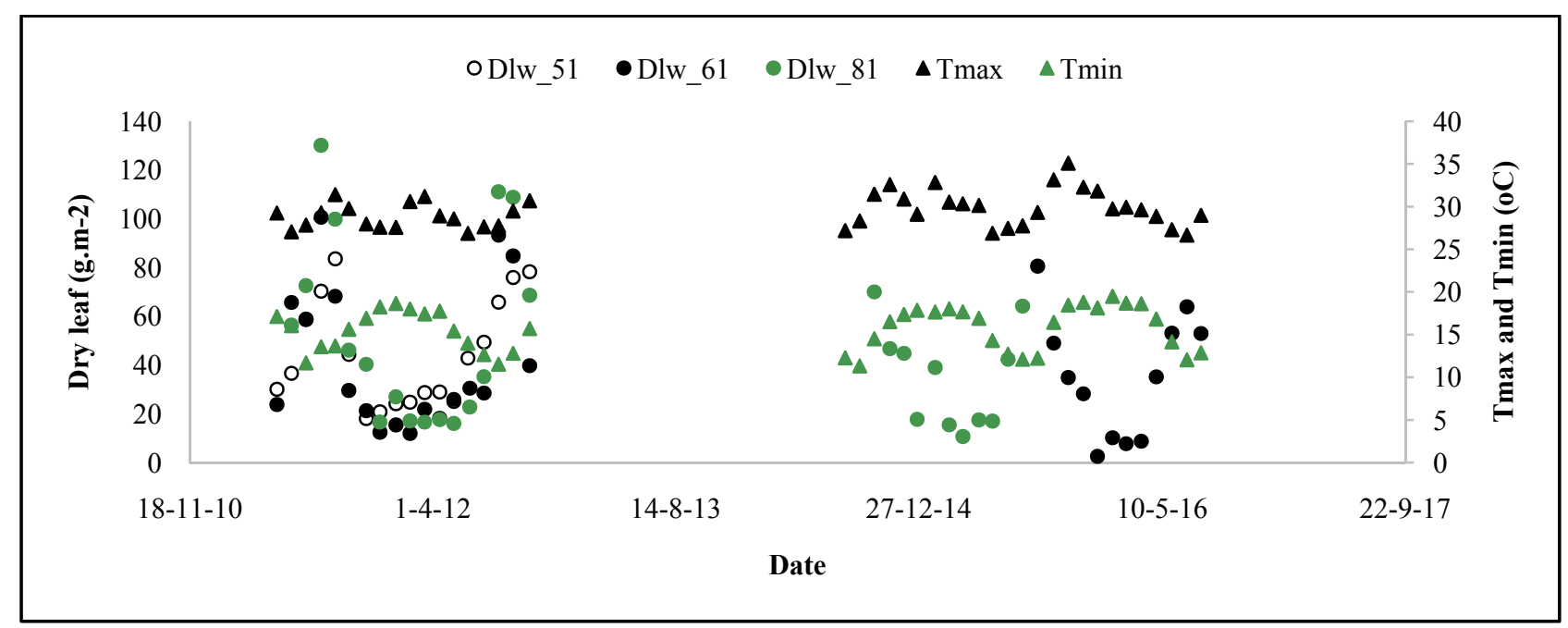

Fig. 6 Relations between dry leaf weight $\left(\mathrm{g} \cdot \mathrm{m}^{-2} \cdot \operatorname{period}^{-1}\right)$ and maximal and minimal temperature in sites 51,61 and 81 . 


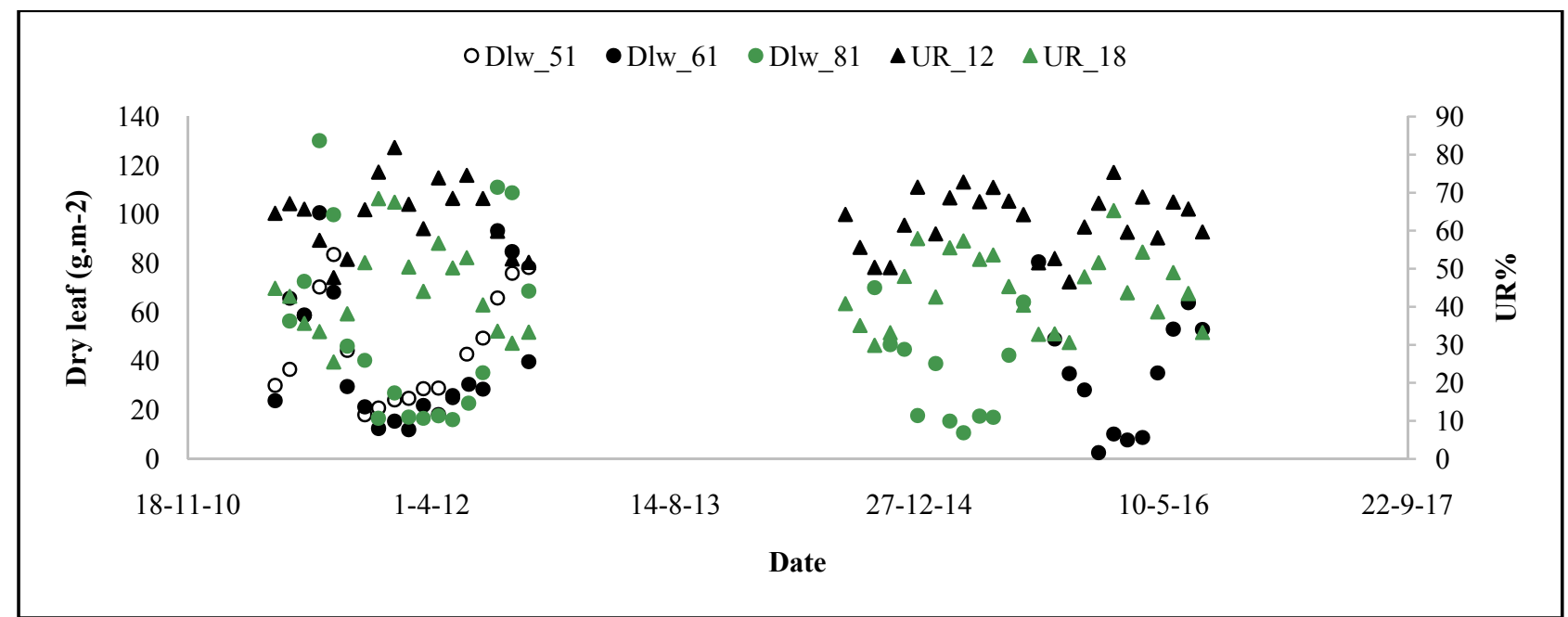

Fig. 7 Relations between dry leaf weight $\left(\mathrm{g} \cdot \mathrm{m}^{-2} \cdot\right.$ period $\left.^{-1}\right)$ and relative humidity on $12 \mathrm{~h}$ and $18 \mathrm{~h}$ UTC (Universal Coordinated Time) in sites 51, 61 and 81.

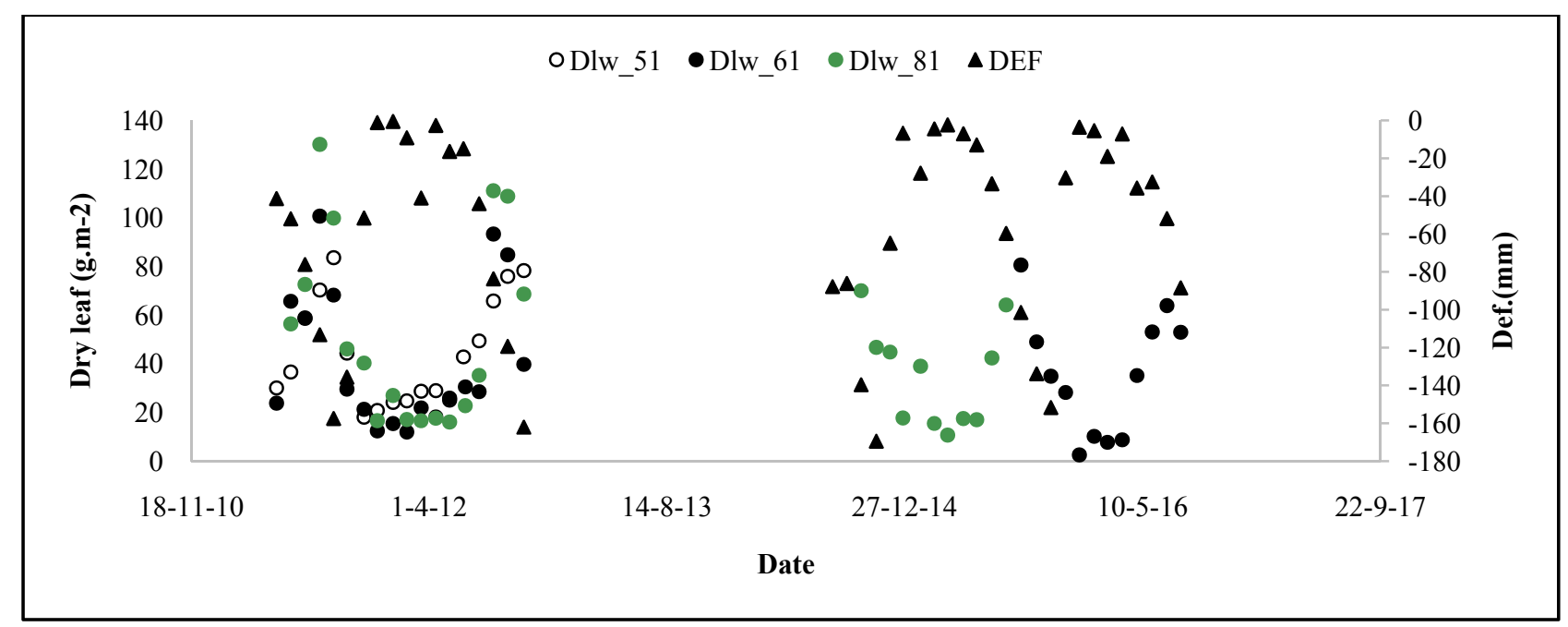

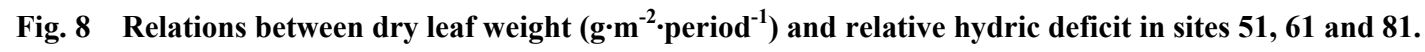

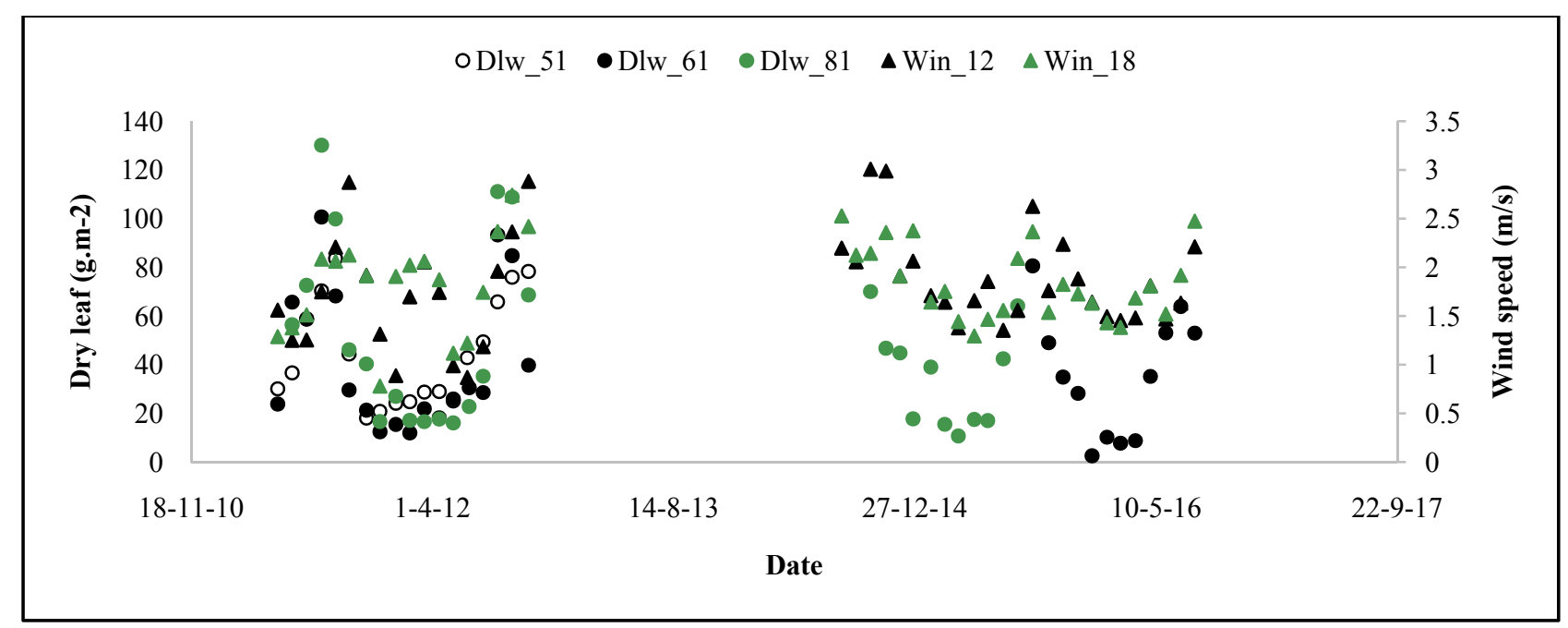

Fig. 9 Relations between dry leaf weight $\left(\mathrm{g} \cdot \mathrm{m}^{-2} \cdot\right.$ period $\left.^{-1}\right)$ and speed wind on $12 \mathrm{~h}$ and $18 \mathrm{~h}$ in sites 51,61 and 81. 
Figs. 10 (a) and (b) show the scatterplots. In Fig. 10 (a), the data present dispersion without bias along the $45^{\circ}$ line. The integration of the monthly estimate in the 12-month period improves the precision. In Fig. 10 (b), the residuals did not present tendency with the observed variable value increase, indicating that there is not a serial correlation, and that heterogeneity of the variances was reduced. It was also verified that the inserted variables are enough to predict the variable Dlw.

Figs. 11 and 12 show the adjustment using the periods 2014/15, 2015/16. The before equations underestimated the bigger values, and the equation published in Costa, T. C. C., et al. [13] had the smaller tendency considering all values. The importance of the new equation is a smaller tendency for bigger Dlw estimations, with greater control including more explanatory variables: the minimal temperature, relative humidity and wind speed.

\section{6 $\mathrm{CO}_{2}$ Fixation Assessment}

The predictions of the $\mathrm{CO}_{2}$ capture by the adjusted

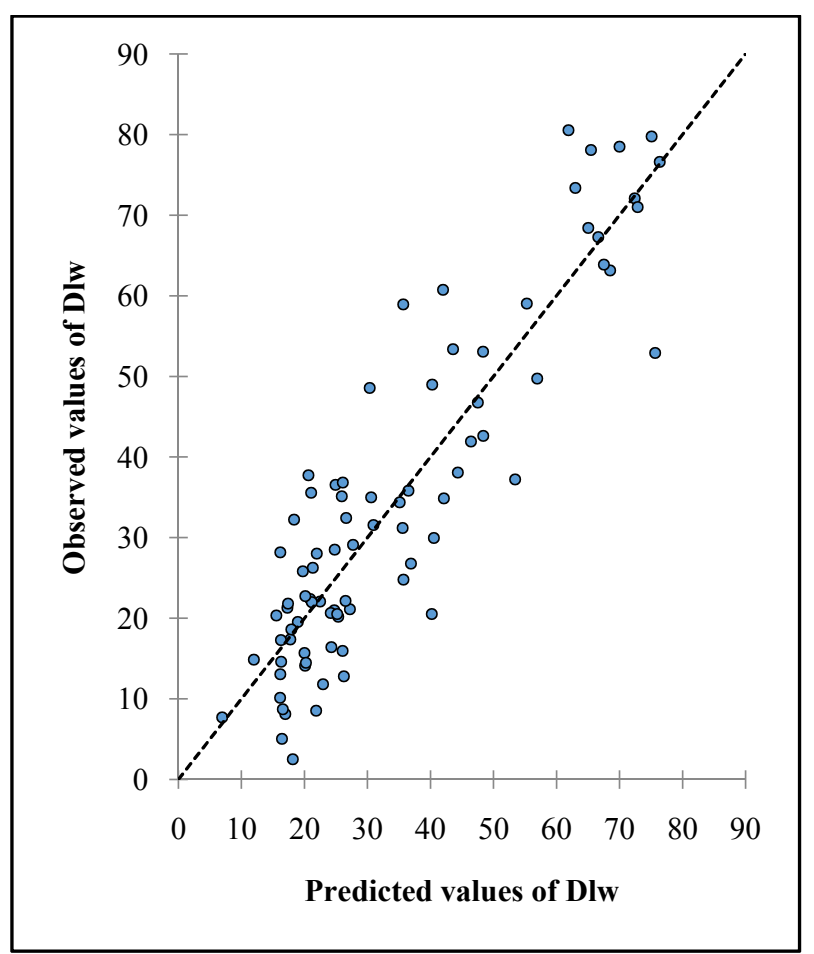

Fig. 10 (a) Observed data in function of the predicted data for the adjusted equation; (b) Dispersion of residuals in function of observed data.

deciduousness dynamics equation, for a period of 12 months in 2011/12 and 2015/16, were compared to the measured data. An annual quantity of carbon is deposited in the soil due to the sprouting process and the seasonal leaf growth and the posterior deposition of this biomass by the deciduousness process. Thus, for each period of 12 months, including the sequence of rainy and water deficit seasons, a measurable amount of $\mathrm{CO}_{2}$ is captured by this forest typology, adding biomass in the trunks, branches and roots, determined by the growth of the vegetation.

However, the greater result of this account is that this amount of $\mathrm{CO}_{2}$ captured occurs each year with renew and deposition of leaves, a sink of carbon.

The estimation of annual leaf deposition was accurate, according to the total of the monthly data (Table 4), with only two biggest errors, 20.2 and 23.1\% in plot 611 of site 61 , and 811 of site 81 , respectively. The average fixation of $\mathrm{CO}_{2}$ among the sites was 6.67 $\mathrm{Mg} \cdot \mathrm{ha}^{-1} \cdot \mathrm{yr}^{-1}$ (observed values) and $6.37 \mathrm{Mg} \cdot \mathrm{ha}^{-1} \cdot \mathrm{yr}^{-1}$ (estimated values).

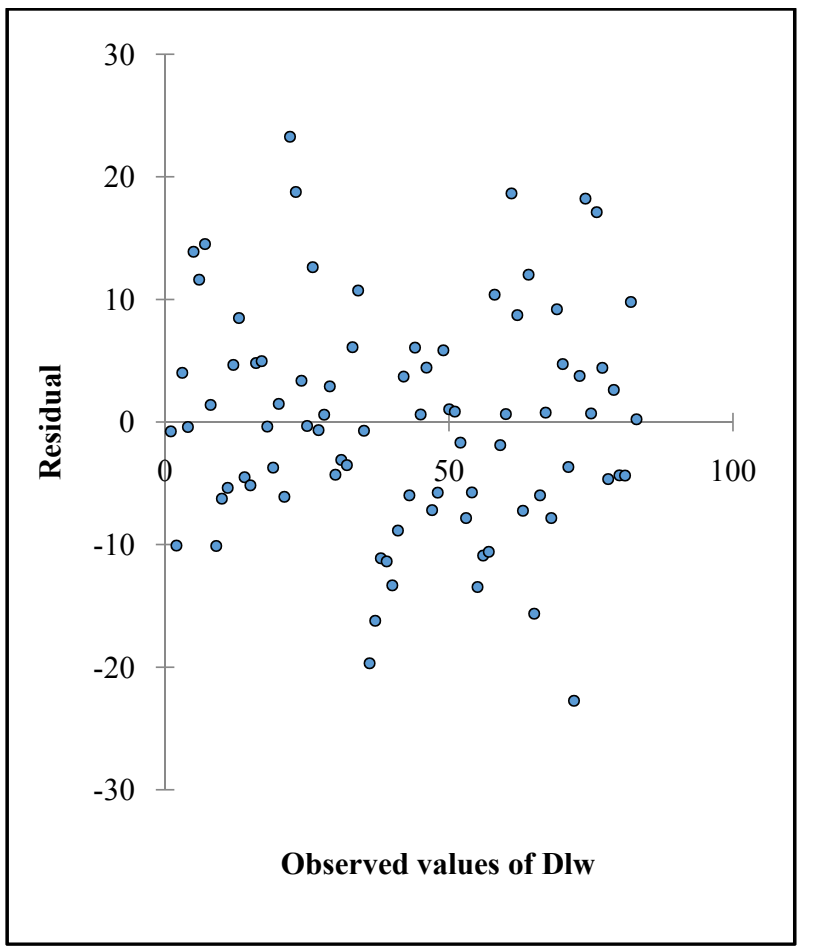




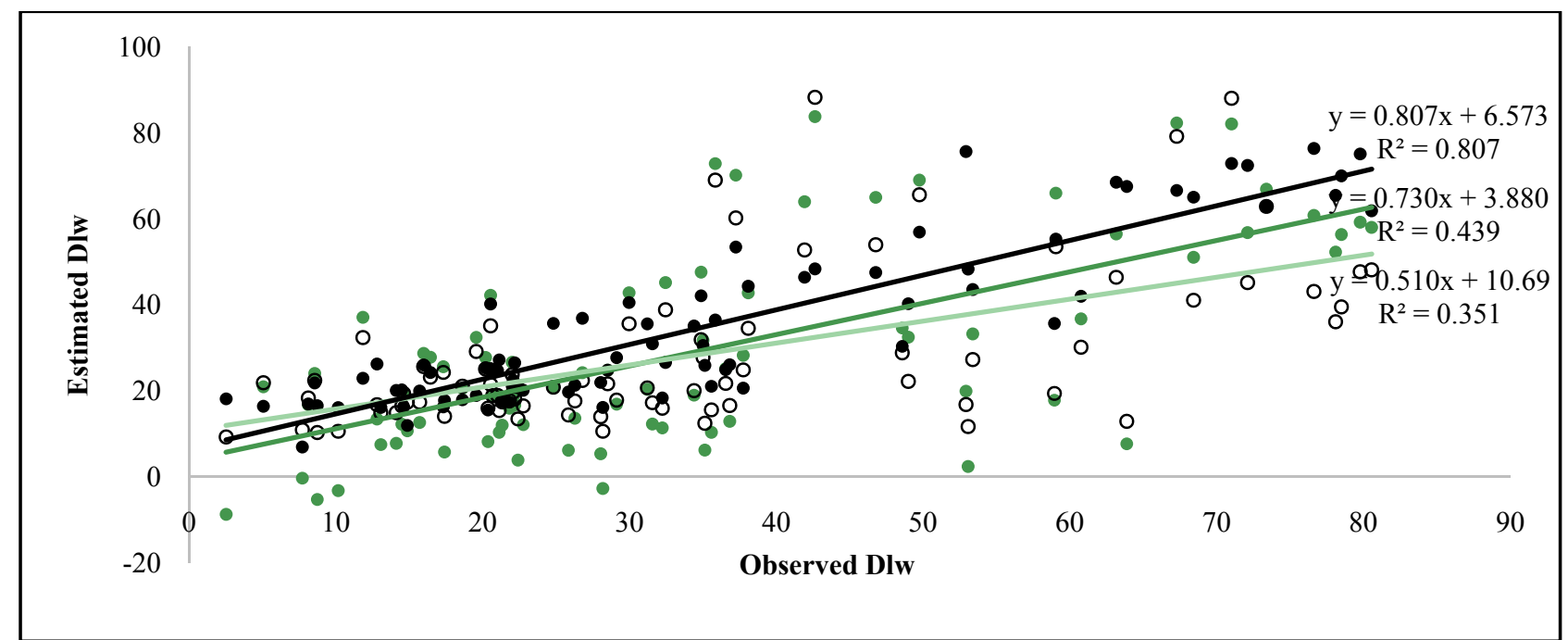

Fig. 11 Scatterplot of the Dlw observed and estimated by equation in [13] (๑), by equation in [14] (०) and by equation (1) in this work $(\bullet)$.

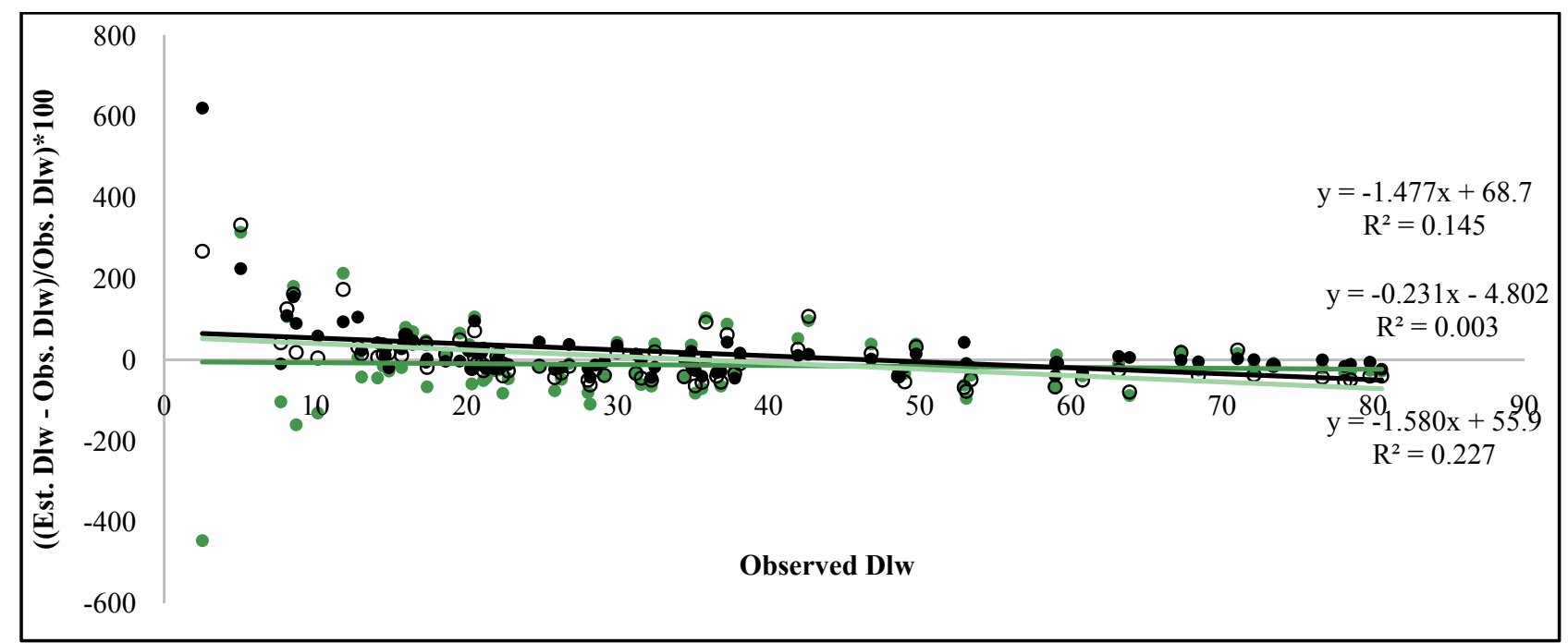

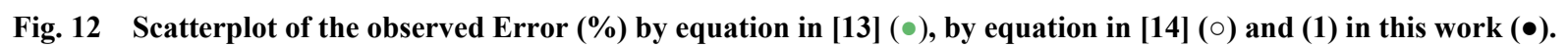

Table 4 Observated, estimated data of Dlw and Error of estimation (\%) to three equations; and observated and estimated data to fixed carbon in the leaves $(\mathrm{C}) *$ and captured $\mathrm{CO}_{2} * *$ calculated by new equation.

\begin{tabular}{|c|c|c|c|c|c|c|c|c|c|c|c|c|}
\hline & & Dlw & Eq.(2013) & Eq.(2014) & Eq.(new) & Er.(2013) & Er.(2014) & Er.(new) & & C est. & $\mathrm{CO}_{2}$ & $\begin{array}{l}\mathrm{CO}_{2} \\
\text { est. }\end{array}$ \\
\hline Period & Plot & \multicolumn{4}{|c|}{$\left(\mathrm{g} \cdot \mathrm{m}^{-2} \cdot \mathrm{yr}^{-1}\right)$} & \multicolumn{3}{|c|}{$(\%)$} & \multicolumn{2}{|c|}{$\left(\mathrm{g} \cdot \mathrm{m}^{-2} \cdot \mathrm{yr}^{-1}\right)$} & \multicolumn{2}{|c|}{$\left(\mathrm{Mg} \cdot \mathrm{ha}^{-1} \cdot \mathrm{yr}^{-1}\right)$} \\
\hline $11 / 10 / 11-13 / 09 / 12$ & 511 & 447.4 & 371.0 & 338.9 & 430.3 & -17.1 & -24.3 & -3.8 & 189.3 & 182.0 & 6.9 & 6.7 \\
\hline $11 / 10 / 11-13 / 09 / 12$ & 512 & 450.9 & 315.3 & 309.1 & 414.4 & -30.1 & -31.4 & -8.1 & 190.7 & 175.3 & 7.0 & 6.4 \\
\hline $11 / 10 / 11-13 / 09 / 12$ & 611 & 467.4 & 372.7 & 383.9 & 372.9 & -20.3 & -17.9 & -20.2 & 197.7 & 157.7 & 7.2 & 5.8 \\
\hline $11 / 10 / 11-13 / 09 / 12$ & 612 & 340.6 & 374.6 & 368.4 & 345.6 & 10.0 & 8.2 & 1.5 & 144.1 & 146.2 & 5.3 & 5.4 \\
\hline $11 / 10 / 11-13 / 09 / 12$ & 613 & 371.9 & 466.6 & 458.4 & 411.6 & 25.5 & 23.2 & 10.7 & 157.3 & 174.1 & 5.8 & 6.4 \\
\hline $28 / 08 / 15-29 / 07 / 16$ & 613 & 426.7 & 154.3 & 207.8 & 435.7 & -63.8 & -51.3 & 2.1 & 180.5 & 184.3 & 6.6 & 6.8 \\
\hline $11 / 10 / 11-13 / 09 / 12$ & 811 & 578.8 & 386.8 & 341.7 & 445.3 & -33.2 & -41.0 & -23.1 & 244.8 & 188.4 & 9.0 & 6.9 \\
\hline $27 / 08 / 14-28 / 07 / 15$ & 811 & 549.5 & - & - & - & & & & & & & \\
\hline
\end{tabular}




\section{Conclusions}

It can confirm the relationship of climatic variables and biophysics remote sensing variables with deciduousness phenomenon in semideciduous seasonal forest. The new model proposed is nonlinear and included more variables to improve consistence. This research needs other experiments to new interannual validations and models test. These sites of the deciduous seasonal tropical forest were confirmed as able to capture average 6.5 tons of $\mathrm{CO}_{2}$ per hectare/year, only due to the deciduousness phenomenon, which will depend on the regeneration stage and forest conservation, besides the other factors used in this equation.

\section{Acknowledgements}

This study is the last result of project CNPq561864/2010-1 "Parameters of forest fragmentation as subsidy for the environment quality and recovery of degraded environments". The author would like to thank the intern team who participated in the acquisition of the data in the second phase of this work: Francimar Roberto da Silva, Vilmar Martins, Leon Sulfierry and Letícia Almeida. The author also would like to thank Antonio Claudio da Silva Barros for the proofreading.

\section{References}

[1] Konig, F. G., Schumacher, M. V., Brun, E. J., and Seling, I. 2002. "Evaluation of the Seasonal Variation of Litter Production in a Seasonal Deciduous Forest in Santa Maria, RS.” Revista Árvore 26 (4): 429-35.

[2] Brun, E. J., Schumacher, M. V., and Vaccaro, S. 1999. "Produção de serapilheira e devolução denutrientes em três fases sucessionais de uma Floresta Estacional Decidual no município deSanta Tereza (RS).” In Anais do Simpósio de Fertilização e Nutrição Florestal, Piracicaba. Piracicaba: ESALQ, 348-64. (in Portuguese)

[3] Feger, K. H., and Raspe, S. 1998. "Ecosystem Research in the Black Forest: Effects of Atmospheric Inputs and Restabilization Measures on the Water and Substance Balance of Spruce Forests.” In Verbundprojekt ARINUS, Reihe Umweltforschung in Baden-Württemberg. Landsberg: Ecomed-Verlag, 1-18.
[4] Cunha, G. C. 1997. Aspectos da Ciclagem de Nutrientes em Diferentes Fases Sucessionais de uma Floresta Estacional do Rio Grande do Sul, (Dissertation) Piracicaba: Escola Superior de Agricultura "Luiz de Queiroz", 86. (in Portuguese)

[5] Soudani, K., Hmimina, G., Delpierre, N., Pontailler, J.-Y., Aubinet, M., Bonal, D., et al. 2012. "Ground-based Network of NDVI Measurements for Tracking Temporal Dynamics of Canopy Structure and Vegetation Phenology in Different Biomes." Remote Sensing of Environment 123: 234-45.

[6] Moreira, F. M. S., and Siqueira, J. O. 2002. Microbiologia e bioquímica do solo. Lavras: UFLA, 625. (in Portuguese)

[7] Barichello, L. R., Schumacher, M. V., Vogel, H. L. M., and Dallago, J. S. 2000. "Quantificação dos Nutrientes no Solo e Serapilheira de Diferentes Estágios Sucessionais em um Sistema de Agricultura Migratória." In Resumos expandidos da Reunião Sul Brasileira de Ciência do Solo. Pelotas (CD-ROM). (in Portuguese)

[8] Potithep, S., Nagai, S., Nasahara, K. N., Moraoka, H., and Suzuki, R. 2013. "Two Separate Periods of the LAI-Vis Relationships Using in situ Measurements in a Deciduous Broadleaf Forest." Agricultural and Forest Meteorology 169: 148-55.

[9] Kale, M., Singh, S., and Roy, P. S. 2005. "Estimation of Leaf Area Index in Dry Deciduous Forests from IRS-WiFS in Central India. Technical Note." International Journal of Remote Sensing 26 (21): 4855-67.

[10] Zhang, X., Friedl, M. A., Schaaf, C. B., and Strahler, A. H. 2004. "Climate Controls on Vegetation Phonological Patterns in Northern Mid- and High Latitudes Inferred from MODIS Data." Global Change Biology 10: 1133-45.

[11] Zhang, X., Friedl, M. A., Schaaf, C. B., Strahler, A. H., Hodges, J. C. F., Gao, F. et al. 2003. "Monitoring Vegetation Phenology Using MODIS.” Remote Sensing of Environment 84: 471-5.

[12] Fensholt, R., Inge Sandholt, I., and Rasmussen, M. S. 2004. "Evaluation of MODIS LAI, fAPAR and the Relation between fAPAR and NDVI in a Semi-arid Environment Using in situ Measurements." Remote Sensing of Environment 91: 490-507.

[13] Costa, T. C. C., Ribeiro, J. L., Ferreira, F. N., Raid, M. A. M., and Miranda, G. A. 2013 Relações entre caducifolia e reenfolhamento da Floresta Estacional Semidecidual com Lai e ndvi. Anais XVI Simpósio Brasileiro de Sensoriamento Remoto-SBSR, Foz do Iguaçu, PR, Brasil, INPE, 3443-3450. (in Portuguese)

[14] Costa, T. C. C., Viana, J. H. M., and Ribeiro, J. L. 2014 "Semideciduous Seasonal Forest Production of Leaves 
and Deciduousness in Function of the Water Balance, LAI, and NDVI." International Journal of Ecology. 2014: 15.

[15] Peel, M. C., Finlayson, B. L., and McMahon, T. A. 2007. "Updated World Map of the Koppen - Geiger Climate Classification." Hydrology and Earth System Sciences 11 (5): 1633-44.

[16] Gomide, R. L., Albuquerque, P. E. P., Andrade, C. L. T., Duraes, F. O. M., and Viana, J. H. M. 2006. "Climatic Characterization and Determination of the Water Requirements of Crops of the Precision Specific Site in Sete Lagoas for Phenotyping of Cereal Genotypes Tolerant to Drought." Alice Repository. Accessed October 30, 2014. http://www.alice.cnptia.embrapa.br/handle/doc/490096.

[17] USDA. 1999. "Soil Taxonomy: A Basic System of Soil Classification for Making and Interpreting Soil Surveys." Agriculture Handbook 436: 871.

[18] Li-Cor. 2011. LAI-2200 Plant Canopy Analyzer: Instruction Manual. Lincoln: Li-Cor Biosciences.

[19] Eastman, J. R. 2009. “ATMOSC”, IDRISI Help System. Accessed in IDRISI Taiga. Worcester, MA: Clark University.

[20] Chavez, P. S. J. 1988. “An Improved Dark-object Subtraction Technique for Atmospheric Scattering Correction of Multispectral Data." Remote Sensing of Environment 24 (3): 459-79.

[21] Gürtler, S., Epiphanio, J. C. N., Luiz, A. J. B., and
Formaggio, A. R. 2005. "Electronic Spreadsheet to Acquire the Reflectance from the TM and ETM+Landsat Images." Revista Brasileira de Cartografia 57 (2): 162-7.

[22] Bird, R. E., and Riordan, C. 1986. "Simple Solar Spectral Model for Direct and Diffuse Irradiance on Horizontal and Tilted Planes at the Earth's Surface for Cloudless Atmospheres." Journal of Climate and Applied Meteorology 25: 87-97.

[23] Maghrabi, A., and Al Dajani, H. M. 2013. "Estimation of Precipitable Water Vapour Using Vapour Pressure and Air Temperature in an Arid Region in Central Saudi Arabia." Journal of the Association of Arab Universities for Basic and Applied Sciences 14: 1-8.

[24] Costa, T. C. C., Silva, A. F., Temponi, L. M., and Viana, J. H. M. 2015. "Probabilistic Classification of Tree and Shrub Vegetation on Phytogeographic System." Journal of Environmental Science and Engineering B 4 (2015): 315-30. doi:10.17265/2162-5263/2015.06.003.

[25] Roy D. P., Kovalskyy, V., Zhang, H. K., Vermote, E. F., Yan, L., Kumar S. S., et al. "Characterization of Landsat-7 to Landsat-8 Reflective Wavelength and Normalized Difference Vegetation Index Continuity." Remote Sensing of Environment 185 (2016) 57-70.

[26] Watzlawick, L. F., Ebling, A. A., Rodrigues, A. L., Veres, Q. J. I., and Lima, A. M. 2011. "Organic Carbon Levels Variation in Tree Species of the MIXED Rain Forest." Floresta e Ambiente 18 (3): 248-58. 